\title{
Frond morphology and epidermal anatomy of Compsopteris wongii (T. Halle) Zalessky from the Permian of Shanxi, China
}

\author{
Malte Backer ${ }^{1} \cdot$ Mingli Wan $^{2} \cdot$ Jun Wang ${ }^{2,3}$
}

Received: 20 December 2018 / Accepted: 28 May 2019 / Published online: 8 July 2019

(c) The Author(s) 2019

\begin{abstract}
Compsopteris wongii (T. Halle) Zalessky is an enigmatic foliage type with unknown systematic affinities endemic to the Permian Cathaysia flora. Here we describe the frond morphology and epidermal anatomy of $C$. wongii based on material from the Palougou Section in Shanxi Province, China. Fronds are petiolate (i.e., possess a naked stipe), are once pinnate, and have alethopteroid, linear-oblong pinnules and a forked apex composed of two equally sized terminal pinnules. Fronds are amphistomatic, with haplocheilic, monocyclic to incompletely tricyclic stomata occurring on all parts. The epidermal anatomy, especially the distribution of stomata, and the lack of features suggestive of xeromorphy indicate that $C$. wongii had a high photosynthetic capacity and high assimilation rates, and was adaptated to an everwet environment. With regard to frond morphology and epidermal anatomy, the species corresponds well to supposedly related peltasperms from Euramerica, such as Glenopteris Sellards and Protoblechnum Lesquereux. We attribute C. wongii to the glenopteroid group of peltasperms.
\end{abstract}

Keywords Cathaysia flora $\cdot$ Protoblechnum wongii $\cdot$ Peltaspermales $\cdot$ Cuticular analysis $\cdot$ Glenopteroids

\section{Introduction}

During the Permian, Earth underwent one of the most extreme climate transitions of the Phanerozoic, from icehouse conditions in the beginning to greenhouse conditions towards the end (Montañez et al. 2007; Montañez and Poulsen 2013). This change was caused by the formation of Pangaea in the Late Pennsylvanian, which had a significant impact on the worldwide climate. Four Late Paleozoic floral provinces have been defined: Gondwana, Angara, Euramerica, and Cathaysia. The Permian Cathaysia flora comprises

Handling Editor: Benjamin Bomfleur.

Jun Wang

jun.wang@nigpas.ac.cn

1 Forschungsstelle für Paläobotanik, Institut für Geologie und Paläontologie, Westfälische Wilhelms-Universität Münster, Heisenbergstraße 2, 48149 Münster, Germany

2 State Key Laboratory of Palaeobiology and Stratigraphy, Center for Excellence in Life and Paleoenvironment, Nanjing Institute of Geology and Palaeontology, Chinese Academy of Sciences, No. 39 East Beijing Road, Nanjing 210008, People's Republic of China

3 University of Chinese Academy of Sciences, No. 19 Yuquan Road, Beijing 100049, People's Republic of China several elements known also from the Carboniferous of Euramerica, but, in addition, contains a number of interesting endemic taxa. Many of these Cathaysian taxa, however, are still known only from adpression fossils of sterile foliage that yield only information on vegetative gross morphology, and whose systematic relationships remain poorly resolved.

One such problematic Cathaysian foliage taxon is Compsopteris wongii (T. Halle) Zalessky 1934. Since its first description by Halle (1927) under the name Protoblechnum wongii Halle 1927, the relationships of this form to morphologically similar taxa from the Euramerican and Angara floral provinces, such as Supaia C. D. White 1929, Glenopteris Sellards 1900, Protoblechnum Lesquereux 1880, and Compsopteris Zalessky 1934, remain debated (DiMichele et al. 2005). Considerations with regard to the relationships between the different forms have hitherto been based exclusively on macromorphological features. Abundant foliage remains of $C$. wongii with well-preserved cuticles, including several near-complete fronds, have recently been recovered from the Guadalupian Lower Shihhotse Formation of the Palougou section in Northwest Shanxi (China). Compsopteris wongii fronds are amphistomatic, with abundant cyclocytic stomata present on the upper and lower surfaces of all frond parts. Our cuticular analysis provides further support to suggest a close relationship between $C$. wongii 


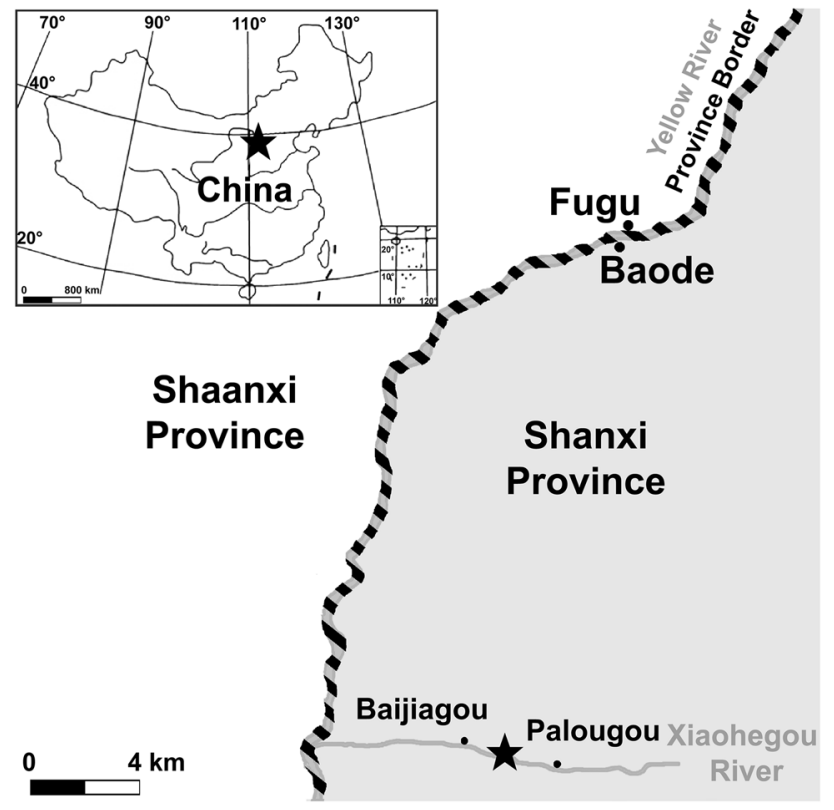

Fig. 1 Location of the Palougou section (black star) (redrawn after Liu et al. 2011 and Kaiser 1976)

and Glenopteris and Nanshanopteris Wan and Wang 2015. Furthermore, we identify $C$. wongii as a representative of the 'glenopteroids,' a group of putative peltasperms so far known only from the Lower Permian of Euramerica and the Upper Permian of Cathaysia.

\section{Geographical and geological setting and materials and methods}

The Palougou section (or Baode section) is located in Baode County in the northwest of Shanxi Province (China), $30 \mathrm{~km}$ south of the county capital of Baode City (Fig. 1). In the valley of the Xiaohegou River, approximately 600-m-thick, slightly westward-dipping Pennsylvanian to Permian rocks are exposed that can be traced over a distance of approximately $6 \mathrm{~km}$ from Palougou village in the east to Bajiagou village in the west. The section comprises a continuous succession of all Pennsylvanian-Permian lithostratigraphic units of the North China block (Li 1995), including (in ascending order) the Benxi, Taiyuan, Shanxi, Lower Shihhotse, Upper Shihhotse, and Sunjagou formations. The Benxi Formation disconformably overlies the Ordovician Majiagou Formation. The Carboniferous Benxi and overlying Pennsylvanian to Permian Taiyuan formations represent marine to continental sediments, while the Shanxi Formation and younger sediments are deltaic and fluvial deposits of meandering river systems (Wang and Chen 2016). The Lower Shihhotse Formation comprises $78 \mathrm{~m}$ of fluvial sediments and is subdivided into two members. The basal
$23 \mathrm{~m}$ of the lower member consist of thick-bedded, yellowish, quartzose sandstones overlain by beds of 1-3 m thick yellow-grayish sandstones alternating with thin-bedded, gray mudstone $1 \mathrm{~m}$ thick. Three coal seams, each less than $1 \mathrm{~m}$ thick, are intercalated between mud- and sandstones. The uppermost of these coal seams marks the boundary with the Upper Member. The Upper Member consists of up to 2-m-thick beds of massive brownish sandstone alternating with thin-bedded, gray silt- and mudstones. Plant macrofossils are abundant in the mudstone beddings, close to the erosional surface of the overlying sandstones. Samples were collected during field work in 2017 from outcrops $300 \mathrm{~m}$ southeast of the village of Liujiapocun in the Xiaohegou River valley, immediately to the north of a local coal mine $\left(38^{\circ} 45^{\prime} 21.57^{\prime \prime} \mathrm{N} ; 111^{\circ} 7^{\prime} 7.96^{\prime \prime} \mathrm{E}\right)$. Bedding numbers, introduced by Liu et al. (2015), were adopted to define the exact stratigraphic provenance of samples. The samples described here were taken from the siltstone beddings 112 and the overlying sandstone beds 113 (Fig. 2). Besides Compsopteris wongii, the flora is rich in typical Cathaysian taxa such as Tingia carbonica (Schenk) T. Halle 1925, Yuania chinensis X. Du and J. Zhu 1982, Mariopteris shanxiensis H. C. Sze 1989, Cladophlebis nystroemii T. Halle 1927, Protoblechnum contractum S. W. S. Gu and W. S. Zhi 1974, and Fascipteris sp., as well as species known from Euramerica including Taeniopteris multinervis, Cordaites schenkii $\mathrm{T}$. Halle 1927, and Cordaites principalis (Germar) Geinitz 1855 .

Specimens were manually prepared via dégagement using sewing needles, and macroscopic photographs were taken using a Canon EOS 7D digital SLR camera equipped with a Canon EFS 60-mm macro lens. Cuticle fragments were easily lifted off the adpression fossils using a preparation needle. Attempts were made to macerate selected cuticle fragments according to standard methods (Kerp 1990; Krings and Kerp 1997). Carbonaceous material was oxidized with Schulze's reagent $\left(\mathrm{HNO}_{3}+\mathrm{KClO}_{3}\right)$ using concentrations increasing from 10 to $20 \%$ for $12 \mathrm{~h}$, followed by treatment with a $5 \%$ potassium hydroxide solution. A $4 \%$ sodium hypochlorite solution was used for additional bleaching and cleaning. After each step, sample material was thoroughly rinsed in distilled water. For most of the cuticle material, however, even this gentle maceration method proved unsuccessful; most of the carbonaceous material completely decomposed after treatment with Schulze's reagent, meaning that, in many cases, only cuticle fragments of the rachis remained sufficiently well preserved for mounting. Permanent microscopic slides were prepared using glycerine jelly. Instead, we analyzed and photographed the epidermal anatomy and cuticle morphology in situ via epifluorescence microscopy using a Leica DM 5500B research microscope equipped with transmitted and incident UV light and with a Leica DFC450 digital microscope camera. Composite 
Fig. 2 Stratigraphy of the Shihhotse Formation and provenance of the sampled sediments (stratigraphy modified after Wang et al. 2008)

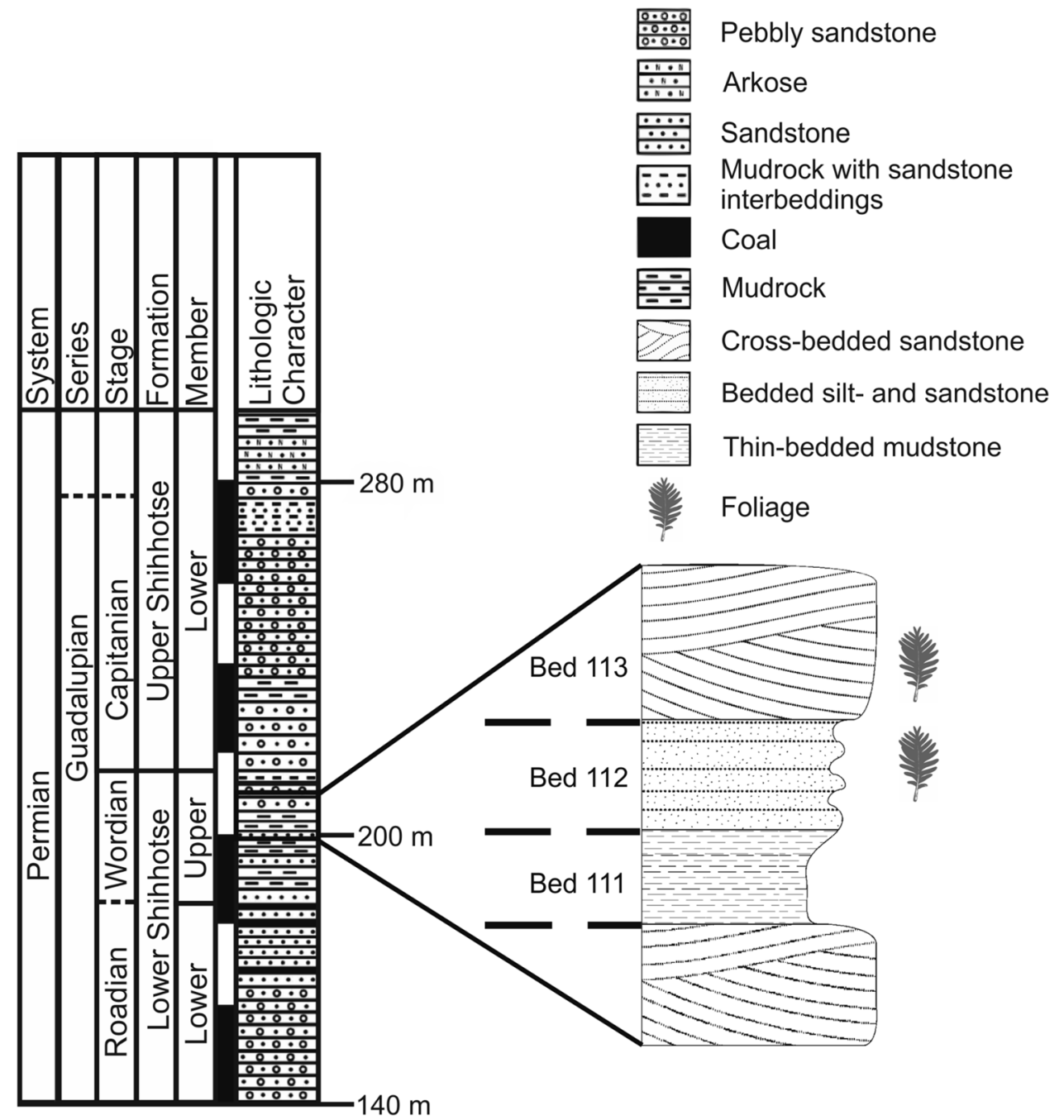

images were produced by stacking and stitching individual images using Photoshop CC and Helicon Focus software. For cropping and conventional adjustments of contrast, brightness, and color, we used Photoshop CC and Corel Graphics Suite X6. Epidermal cells and stomata were measured with Leica LAS 4.5 software.

\section{Systematic part}

\section{Class Pteridospermatophyta \\ Order Peltaspermales Delevoryas 1979}

Genus Compsopteris (Zalessky) Naugolnykh 1999 emend. herein

Type species. Compsopteris adzvensis Zalessky 1934
Diagnosis. Fronds pinnate, petiolate, with prominent rachis. Pinnules oblong, straight or slightly curving, with entire margins and rounded apex; pinnules small and attached about perpendicular to rachis in the basal frond portion, becoming longer and arising at increasingly acute angles towards the apex; lowermost pinnules with a constricted base; towards the apex, pinnules becoming more broadly attached to decurrent or auriculate. Frond apex forked to form a single, basally confluent pair of terminal pinnules. Venation alethopteroid; midrib strong, reaching close to tip; secondary veins arising at acute angles, simple or forking up to four times. Wing-like decurrent basiscopic pinnule portions with veins arising directly from rachis. Fronds amphistomatic; stomata haplocheilic, cyclocytic.

Remarks. The recent emendation of the genus (Naugolnykh 1999) lacked important information on cuticle features (see Meyen and Migdisova 1969) and included the following 
Table 1 Simplified macroscopical comparison of Compsopteris wongii to possibly related pinnate taxa

\begin{tabular}{|c|c|c|c|c|c|c|c|c|}
\hline \multirow[t]{2}{*}{ Taxa } & \multicolumn{3}{|c|}{ Frond architecture } & \multicolumn{3}{|l|}{ Pinnules } & \multicolumn{2}{|c|}{ Venation } \\
\hline & $\begin{array}{l}\text { Frond } \\
\text { bifurcation }\end{array}$ & Petiolate & Apex forking & $\begin{array}{l}\text { Apical pin- } \\
\text { nules connate }\end{array}$ & $\begin{array}{l}\text { Adaxially } \\
\text { attached }\end{array}$ & $\begin{array}{l}\text { Pinnules } \\
\text { auriculate }\end{array}$ & $\begin{array}{l}\text { Midrib } \\
\text { distinct }\end{array}$ & Bifurcations \\
\hline Compsopteris wongii ${ }^{\mathrm{a}}$ & - & + & + & - & + & \pm & + & $1-2$ \\
\hline Compsopteris adzvensis ${ }^{\mathrm{b}}$ & - & $?$ & + & - & $?$ & \pm & + & $1-4$ \\
\hline Glenopteris $^{\mathrm{c}}$ & - & + & - & + & + & + & - & $0-1$ \\
\hline Supaia $^{\mathrm{d}}$ & + & + & - & + & $?$ & \pm & + & $1-2$ \\
\hline Megalopteris $^{\mathrm{e}}$ & $?$ & $?$ & + & + & $?$ & + & + & $1-3$ \\
\hline Nanshanopteris ${ }^{\mathrm{f}}$ & - & + & - & + & - & + & - & 4 \\
\hline
\end{tabular}

${ }^{a}$ Halle (1927); this study

${ }^{\mathrm{b}}$ Zalessky (1934), Meyen and Migdisova (1969) and Naugolnykh (1999)

${ }^{\text {c}}$ Sellards (1900) and Krings et al. (2005)

${ }^{\mathrm{d}}$ White (1929)

${ }^{e}$ Dawson (1871) and Andrews (1875)

${ }^{\mathrm{f}}$ Wan and Wang (2015)

problematic terms that we have omitted here. The frond architecture was described as 'imparipinnate,' whereas all sufficiently complete specimens instead show a forking apex with a terminal pinnule pair (Halle 1927; Meyen and Migdisova 1969; Naugolnykh 1999: Table 1). In addition, the terms 'sphenopteroid' and 'pecopteroid' were used to describe a constricted versus broadly attached pinnule base; these terms are, however, conventionally also used to describe venation and margin features, and are thus potentially misleading.

Compsopteris wongii (T. Halle) Zalessky 1934 emend. nov. Figures 3, 4, 5

\section{Basionym. Protoblechnum wongii T. Halle 1927.}

Syntypes. Ten specimens from the Shihhotse Formation, Shanxi Province, North China, described and figured in Halle (1927) as follows: Lower Shihhotse Formation, East Section, bed 18: specimen S138216 (apical frond fragment; pl. XXXV, fig. 1); Upper Shihhotse Formation, West Section, bed 25: specimen S138217 (basal petiolate frond fragment; pl. XXXV, fig. 2); Upper Shihhotse Formation, East Section, bed 21: specimen 138218 (frond fragment; pl. XXXV, fig. 3), specimen 138219 (frond fragment; pl. XXXV, fig. 4), specimen 138220 (basal frond fragment; pl. XXXV, fig. 5); Upper Shihhotse Formation, East Section, bed 21: specimen S138221 (frond fragment of lower part; pl. XXXVI, fig. 1), specimen 138222 (frond fragment near the base; pl. XXXVI, fig. 2); specimen 138223 (apical frond fragment with terminal bifurcation; pl. XXXVI, fig. 3); specimen 138224 (apical frond fragment with terminal bifurcation; pl. XXXVI, fig. 4); specimen 138225 (small, undeveloped fronds given off from rhizome; pl. XXXVI, fig. 5); specimen S138380 (apical frond fragment with terminal bifurcation; pl. LXIV, fig. 12); all housed in the Palaeobiology Collections of the Swedish Museum of Natural History, Stockholm, Sweden.

Epitypes (designated here). Three specimens from the Lower Shihhotse Formation at the Palougou Section, NW Shanxi Province, North China, as follows: specimen PB22968, a complete frond with apex; specimen PB22972, large petiolate frond fragment; specimen PB22974, frond fragment with well-preserved venation and apex. All samples show cuticular preservation and are housed in the Palaeobotanical Collections of the Nanjing Institute of Geology and Palaeontology, Nanjing, China.

Additional material. Specimens housed in the Palaeobotanical Collections of the Nanjing Institute of Geology and Palaeontology, Nanjing, China: PB22966, PB22967, PB22969, PB22970, PB22971, PB22973, PB22975, PB22976, PB22977, PB22978, PB22979.

Locality of examined material. Bedding numbers 112 and 113, Lower Shihhotse Formation, Upper Member, Palougou Section, Shanxi Province, North China; coordinates: $38^{\circ} 45^{\prime} 21.57^{\prime \prime} \mathrm{N}, 111^{\circ} 7^{\prime} 7.96^{\prime \prime} \mathrm{E}$

Emended specific diagnosis. Fronds large (exceeding $40 \mathrm{~cm}$ in length), ovate in outline, petiolate, pinnate. Frond apex forking into two equally sized pinnules. Rachis prominent, channeled on upper side, keeled on lower. Pinnules closely spaced, arising at angles of 50-60 from the rachis in median portion of frond, in upper portion more oblique, in lower portion more extended, at the base commonly perpendicular or reflexed. Pinnules broadly attached, basally decurrent to 
almost confluent with or slightly overlapping the subjacent pinnule margin. Decurrent wings wide, in the upper frond portion flat, in lower portion curving towards upper side of rachis in an auriculate manner, becoming gradually more indistinct towards frond base, lacking in lowermost pinnules. Pinnules linear, entire-margined, gradually tapering towards obtuse or subacute apex. Venation alethopteroid; midrib strong, reaching close to tip; secondary veins arising at narrow angle, arching, reaching margin at angles of $50-60^{\circ}$ in median pinnule portion, usually forking once or twice, rarely simple. Veins in auricles directly arising from rachis, almost perpendicularly, bifurcating once. Fronds amphistomatic. Rachis, midrib, and pinnule lamina stomatiferous. Epidermal cells of rachis, midrib, and costal fields polygonal-elongate, epidermal cells of intercostal fields polygonal-isodiametric. Haplocheilic stomata longitudinally oriented on rachis and midrib, randomly oriented and distributed on lamina; monocyclic to incompletely tricyclic. Large multicellular trichomes randomly distributed on rachis.

Detailed description. Fronds are large, ovate, with alethopteroid pinnules and a basally widening petiole (Fig. 3a, b). The largest specimen at hand is an almost complete frond $44 \mathrm{~cm}$ long and $30 \mathrm{~cm}$ wide. The rachis is thick, marked by longitudinal striae, and attains a breadth of up to $6 \mathrm{~mm}$ on the impression of the pinnule-bearing portion. The petiole is basally widened and up to $14 \mathrm{~mm}$ wide (Fig. 3a). Two equally sized, small pinnules occur distally (Fig. 3a, b, d). Pinnules are linear-oblong, densely arranged, and decrease in size towards the base of the frond, attaining a maximum length of $17 \mathrm{~cm}$ and width of $4 \mathrm{~cm}$. The auricle is variably well developed; in some specimens (Fig. 3e) it reaches or even slightly overlaps the subjacent pinnule; in other specimens with pinnules in a similar position on the frond, the leaf base is only slightly decurrent on the rachis. The wings are in many cases curving up on the upper side of the rachis and are absent in the lowermost, smallest pinnules (Fig. 3c, f). The auricle is widest in the two apical pinnules. The lamina of the pinnules is attached to the top of the midrib, which is generally $1 \mathrm{~mm}$ wide and reaches to near the pinnule apex. Lateral veins arise from the midrib at angles of $10-15^{\circ}$, gradually arch in an outward direction, and reach the margin at angles of $\sim 50-60^{\circ}$. Veins usually fork once or twice in their course to the margin, or are rarely simple (Fig. 3e, f). In the decurrent wings, the lateral veins are given off directly from the rachis at angles of $80-90^{\circ}$ and fork once to twice.

The fronds are amphistomatic, and stomata occur on all parts of the frond. Epidermal cells are generally elongate in the costal fields and isodiametric in the intercostal fields (Fig. 4a). Anticlinal walls are strongly cutinized, periclinal walls are smooth. Stomatal complexes are generally haplocheilic and monocyclic to incompletely tricyclic. The upper surface of the rachis is obscured as pinnules are adaxially attached (Fig. 4b). On the lower surface of the rachis, cells are elongate, with straight lateral and oblique polar anticlinal walls, 48-(105)-236 $\mu \mathrm{m}$ long and 5-(16)-26 $\mu \mathrm{m}$ wide, and arranged in longitudinal rows (Fig. 4c, d). Stomatal complexes are longitudinally oriented, monocyclic, arranged parallel to the cells of the midrib, and 91-(103)-112 $\mu \mathrm{m}$ long and 50-(61)-72 $\mu \mathrm{m}$ wide. Large multicellular, truncate trichomes are randomly distributed, occur isolated or in pairs, and range in shape from slight swellings of the cuticle to thick cylindrical protrusions with an apical opening, measuring up to $340 \mu \mathrm{m}$ in length and $214 \mu \mathrm{m}$ in width (Fig. 4e). In many cases, the opening is filled with a black, amorphous substance (Fig. 4c, d).

Similar to the frond rachis, the upper side of the pinnule midrib is obscured because the pinnule lamina is adaxially attached. On the lower surface of the pinnule midrib, the epidermal pattern and stomata distribution are similar to those of the rachis, but trichomes are absent. On both sides of the lamina, the epidermis is only weakly differentiated into costal and intercostal fields (Fig. 4a). Cells in the intercostal fields are randomly oriented, isodiametric, $18-(41)-82 \mu \mathrm{m}$ in diameter. Costal fields consist of undulating rows of elongate cells similar to those of the midrib and rachis; they are one or two cells wide on the upper pinnule lamina and three to five cells wide on the lower pinnule lamina. Stomatal complexes are distributed and oriented randomly in the intercostal fields, slightly sunken and monocyclic to incompletely tricyclic, with 6-8 subsidiary cells and up to 12 additional encircling cells. Stomatal complexes are 92-(120)-147 $\mu \mathrm{m}$ long and 80-(103)-126 $\mu \mathrm{m}$ wide (Fig. 4f-g).

Taxonomic remarks and comparisons. Halle (1927) erected the species Protoblechnum wongii based on pinnate fronds with a dichotomously forking tip and elongate, auriculate pinnules from the Shanxi Province in North China. However, Protoblechnum and its type species $P$. holdenii (E. D. Andrews) Lesquereux 1880 from the Pennsylvanian coal measures of Ohio, USA, are rather poorly known. The type material does appear superficially similar in overall gross morphology, but does not show unambiguous information on the diagnostic frond apex. No photographs are available, and in the single existing illustration of an apical frond portion (Andrews 1875: pl. LI, figs. 1, 2), the frond apex is covered by a thin layer of sediment on which an obviously separate leaf fragment is preserved. The arrangement of the central and apical portions of the apical pinnules is rather suggestive of the presence of just a single median pinnule instead of a true pair of terminal pinnules. This is further supported by the illustrations of an additional, near-complete frond that was collected in 1952 from the original type locality of $P$. holdenii (Cross et al. in Feldmann 1996: figs. 23-26:4, 5). This specimen also bears 


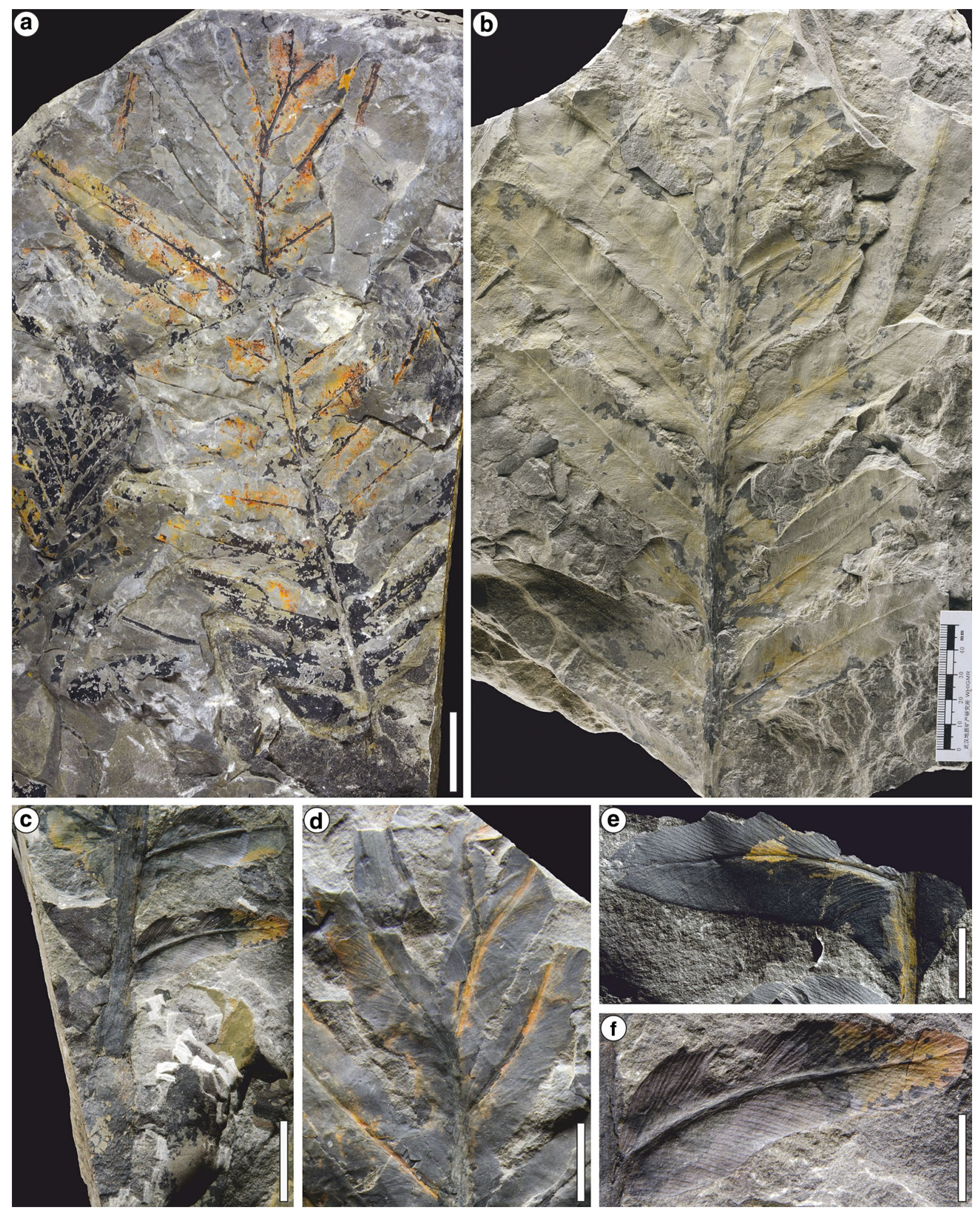


4Fig. 3 Frond morphology of Compsopteris wongii. a Almost complete frond of $C$. wongii showing apical forking and petiole. Specimen PB22968, scale bar $5 \mathrm{~cm}$. b Distal frond fragment with characteristic apical forking and slightly overlapping pinnules. Specimen PB22974, scale bar $5 \mathrm{~cm}$. c Proximal portion with widened, scaly petiole. Specimen PB22972, scale bar $2 \mathrm{~cm}$. d Apical frond fragment showing forking tip and overlapping pinnules. Specimen PB22969, scale bar $1 \mathrm{~cm}$; e Pinnule in the lower part of the frond with decurrent leaf bases and secondary veins arising directly from rachis. Specimen PB22979, scale bar $1 \mathrm{~cm}$. f Magnification from $\mathbf{c}$ showing details of lowermost pinnule without decurrent leaf base. Specimen PB22972, scale bar $1 \mathrm{~cm}$

fused apical pinnules that decrease in size towards the apex and terminate in a single (i.e., non-dichotomizing) terminal pinnule. Altogether, there is thus good evidence that the frond architecture of the type species Protoblechnum is similar to that of Glenopteris and different from that of Compsopteris, including C. wongii.

Later, Zalessky (1934) erected the genus Compsopteris for similar fossils from the Petchora Basin in Russia and included the Chinese fronds in this genus. Several authors adopted Zalessky's new combination and used the name Compsopteris wongii (e.g., Gu and Zhi 1974; Naugolnykh and Kerp 1996; Sun 2006); others continued to use Halle's Protoblechnum wongii and pointed out the need for epidermal studies on the Chinese material for detailed comparisons of the two genera (e.g., Chow 1955; Liu 1989; Krings et al. 2005; Taylor et al. 2009; Wan and Wang 2015). Our results now show that the type species of Compsopteris, C. adzvensis Zalessky 1934 from the Angaran realm, is macroscopically and microscopically very similar to $C$. wongii. Fronds possess a distinct petiole, a dichotomously forking tip, elongate pinnules with a more or less well-developed auricle, and amphistomatic pinnules with cyclocytic stomatal complexes (Zalessky 1934; Meyen and Migdisova 1969). It is distinct from $C$. wongii in the significantly smaller size of the frond, with more repeatedly forking secondary veins, monocyclic to dicyclic (as opposed to mono- to incompletely tricyclic) stomatal complexes, papillate subsidiary cells, but without trichomes. Compsopteris olgae Naugolnykh 1999 and C. tchirkovae Zalessky 1934 are very similar to $C$. wongii but poorly defined, and may need to be synonymized with $C$. wongii.

\section{Discussion}

\section{Comparisons}

Compsopteris wongii belongs to a group of foliage genera from the Late Palaeozoic, such as Glenopteris, Nanshanopteris, Supaia, and Megalopteris Dawson 1871 (Tables 1, 2).

Glenopteris from the Lower Permian of Euramerica has often been proposed as a close relative of Compsopteris wongii (e.g., Halle 1927; White 1929; Krings et al. 2005; Sun and Shen 1999a, b). The type species Glenopteris splendens Sellards 1900 shares many similarities in macromorpholgy and especially epidermal anatomy with $C$. wongii; the main differences concern the architecture of the frond tip and the simple, indistinct venation in the former (Table 1). Furthermore, cuticles of $C$. wongii do not show the peg-like projections in the anticlinal walls that are a typical feature of G. splendens (Krings et al. 2005), although anticlinal walls are thickened. Differences dfrom the second glenopteroid species Nanshanopteris nervosa Wan and Wang 2015 from China are mainly the same as from $G$. splendens, with the addition that epidermal cells of the former bear papillae (Wan and Wang 2015). However, papillae are not necessarily of high taxonomic relevance; they may instead reflect paleoecological adaptation (Poort and Kerp 1990). Both of these glenopteroids occured in seasonal Permian environments: G. splendens from the Artinskian of Euramerica in a coastal environment periodically affected by seasonality and soil and ground water salinity (Krings et al. 2005), and $N$. nervosa from the Changhsingian of China on a well-drained lacustrine shore under a seasonally wet climate (Wan and Wang 2015). C. wongii from the Guadalupian of China clearly lived in a tropical, everwet environment close to a meandering river system (Liu et al. 2015). It is therefore not surprising that epidermal features such as papillae, peg-like projections, or other supposedly xerophytic adaptations are absent.

Another interesting genus is Supaia, initially described from the Permian of Euramerica (White 1929). It differs from Compsopteris in its bipartite, imparipinnate frond architecture. Wang (1997) recorded Supaia fronds from the Capitanian Tianlongsi Formation (another name for the Upper Shihhotse Formation) of Shanxi and proposed it might represent a descendent of Compsopteris wongii that is morphologically adapted to a semi-arid environment. Pinnules of S. contracta Wang 1997 are amphistomatic, with monocyclic to dicyclic and slightly sunken stomata somewhat comparable to those of $C$. wongii. These similarities in the epidermal anatomy to $C$. wongii suggest a close relationship, with the main differences being the architecture, the contracted leaf bases, and the papillae on the cells of lower leaf sides of $S$. contractum.

Megalopteris from the Pennsylvanian of Euramerica is superficially similar, but most species were described based on small fragments, yielding limited information on frond architecture and morphology that is insufficient for detailed comparison (Table 1). Moreover, those three species for which cuticles have been described differ from Compsopteris wongii in that they are indicative of hypostomatic leaves (Florin 1933). 

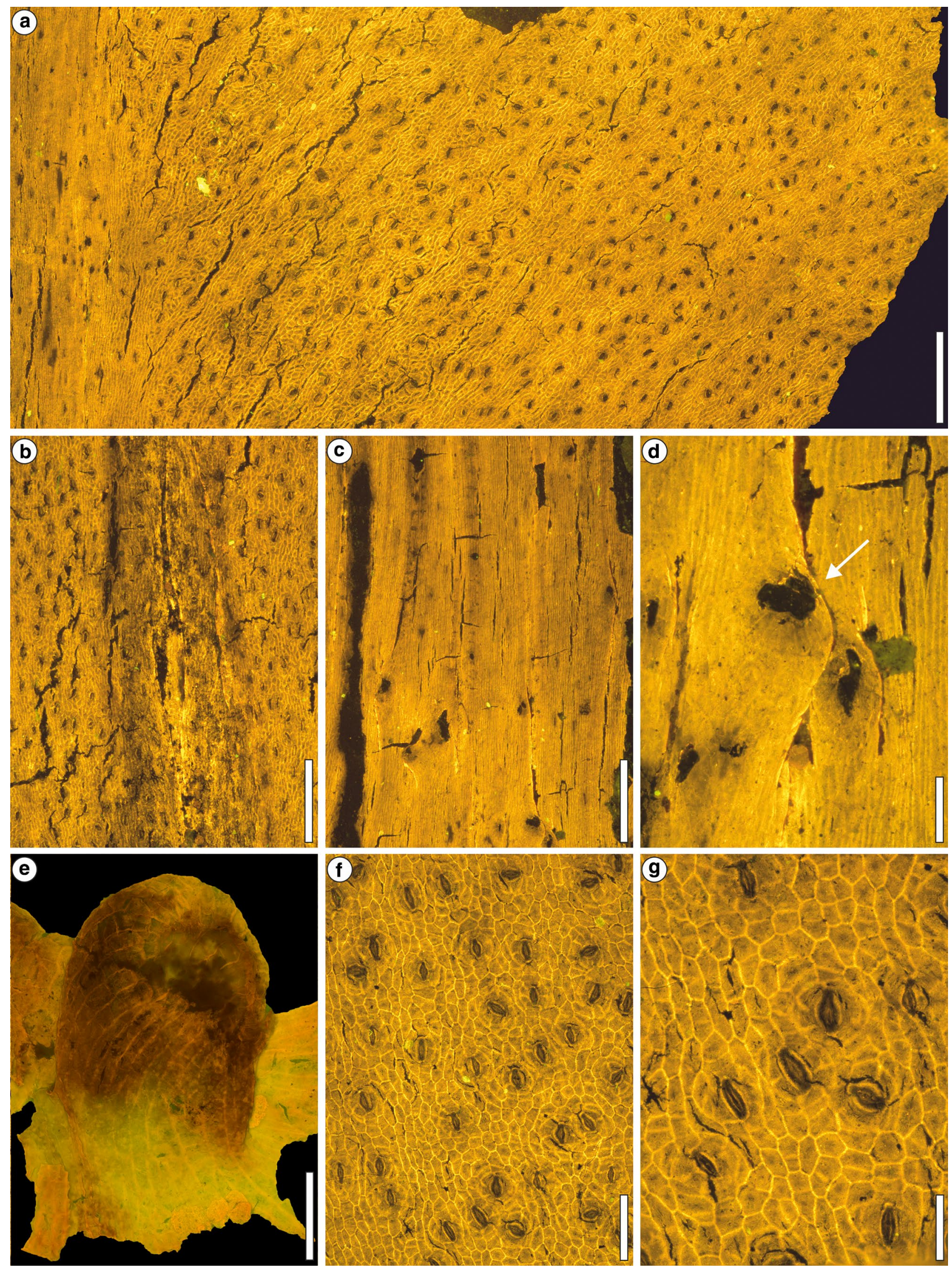
४Fig. 4 Epifluorescence images of epidermal anatomy of Compsopteris wongii. a Lower pinnule surface with longitudinally arranged cells and stomata on midrib (left) and lamina with ill-defined costal and intercostal fields and high densities of randomly oriented stomata. Specimen PB22968, scale bar $100 \mu \mathrm{m}$. b Upper view showing the adaxial attachment of lamina to midrib, which is only visible as a cleft. Specimen PB22978, scale bar $500 \mu \mathrm{m}$. c Lower view of the rachis showing longitudinally oriented cells and randomly distributed glandular trichomes. PB22979, scale bar $500 \mu \mathrm{m}$. d Close-up of two trichome bases with truncate apex and opaque filling (arrow). Specimen PB22978, scale bar $100 \mu \mathrm{m}$. e Macerated trichome with apical opening. Specimen PB22978, scale bar $100 \mu \mathrm{m}$. f Intercostal field with randomly oriented, cyclocytic stomata. PB22979, scale bar $200 \mu \mathrm{m}$. g Group of mono- to dicyclic stomata in an intercostal field. PB22979, scale bar $100 \mu \mathrm{m}$

\section{Paleobiology and paleoecology}

The paleoenvironment of the Lower Shihhotse Formation in Shanxi was interpreted as a fluvial system with meandering rivers and a tropical, humid climate with no periods of seasonal dryness (Liu et al. 2015; Wang and Chen 2016). Specimens of Compsopteris wongii from this site are usually large fragments, including almost complete fronds more than $20 \mathrm{~cm}$ in size. Thus it is unlikely that they were transported over long distances; they were probably deposited close to their habitat. The associated flora in this habitat is rich in Noeggerathialeans such as Tingia carbonica, Cordaitaleans as Cordaites principalis and Cordaites schenkii, and putative cycads such as Taeniopteris cf. multinervis. All these species have amphistomatic leaves with no xeromorphic adaptations and are typical coal-forming elements in Cathaysian floras. For instance, these genera have all been found to be very common elements in the peat-forming swamp forest of the Asselian (Early Permian) Wuda Tuff Flora (Chinese "vegetational Pompeii") (Wang et al. 2012).

The epidermal anatomy of Compsopteris wongii also shows distinct adaptations to this environment, as pinnules are amphistomatic and do not show xeromorphic adaptations such as papillae, strongly sunken stomata, or trichomes. Furthermore, the high density of stomata on both sides of leaves, the midrib, and rachides indicate an adaptation to allow high photosynthetic capacities and assimilation rates (Mott et al. 1982; Smith et al. 1997; Bomfleur and Kerp 2010). This effect may have been enhanced by the attachment of the lamina to the very top of the midrib, which additionally increased the upper (sun-facing) surface of the lamina. Another interesting feature is that cuticles of $C$. wongii commonly show intense fracturing even in freshly split material, which may result from shrinkage and compaction of a particularly thick leaf substance. Fleshy or succulent pinnules can be an adaption to water stress or soil and groundwater salinity (Krings et al. 2005), but both of these interpretations are unlikely as $C$. wongii lived neither in a (seasonally) dry environment nor in a coastal habitat (Liu et al. 2015).
Another interpretation could be that the thickened pinnules were another adaptation to the high assimilation rates of $C$. wongii, in that the increased pinnule thickness would have substantially increased the mesophyll cell-surface area available for carbon dioxide absorption (Smith et al. 1997).

The distribution of trichomes in Compsopteris wongii is limited to the rachis, and their low density indicates that they did not have a defence function as a mechanical barrier against predators. Their shape and especially the opaque filling of their apical opening suggest that they were glandular structures, very similar to specimens of the peltasperm Autunia conferta that were recovered from peat-forming environments (Kerp 1996). Remarkably similar glandular trichomes also occur in extant plants, e.g., Lamiaceae or Cannabaceae (e.g., Werker 2000; Andre et al. 2016). In modern plants, such trichomes have different functions, depending on their location and the substance they secrete (Werker 2000). They can store and excrete lipophilic or hydrophilic secondary metabolic products as oils or mucilage, or excrete excessive nutrients as salts (Krings and Kerp 1998; Werker 2000). Without knowing which of these substances the trichomes of C. wongii secreted, however, we cannot identify their function precisely.

\section{Reconstruction of the frond}

Different frond fragments of Compsopteris wongii could be unequivocally correlated to the same plant based on similarities in macromorpholgy and especially epidermal anatomy. Fronds are simple pinnate with a forking tip, distinct petiole, and more or less auriculate, alethopteroid pinnules (Fig. 5). Features consistent among specimens are the typical dichotomous branching of the frond tip, the absence of auricles in the lowermost small pinnules, and the distinct, widened petiole of the frond. A certain degree of variability between individual fronds occurs with regard to the manifestation of the auricles and the level of overlap of superimposing pinnules, with both features well-developed to inconspicuous. Furthermore, our results show that fronds of $C$. wongii were monopodial rather than forked, a feature already recognized by Halle (1927). We restudied samples of supposedly forked fronds of $C$. wongii from the Upper Shihhotse Formation of southeast Shanxi (Chow et al. 1955; Sze 1955), but these samples are questionable as they are either two superimposed fronds or frond fragments that are quite different in shape and venation from those of $C$. wongii. The reports of supposedly bipinnate fronds-including specimens of $C$. wongii (Liu 1989) and of P. contractum (Gu and Zhi 1974; Sun and Shen 1999a, b) — remain doubtful, as the fronds are linear and pinnules are uniformly sized and broad with an indistinct midrib (Liu 1989). Unfortunately, none of these samples has a preserved frond tip. Another very interesting specimen in regard to the growth habit of $C$. wongii 


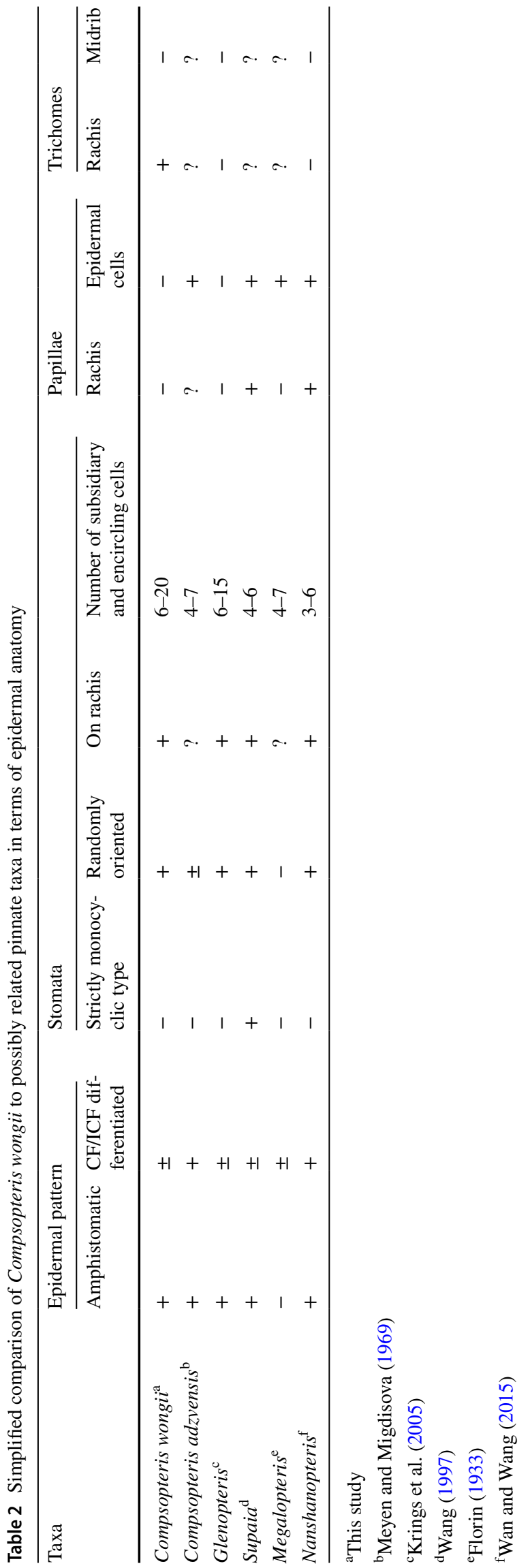

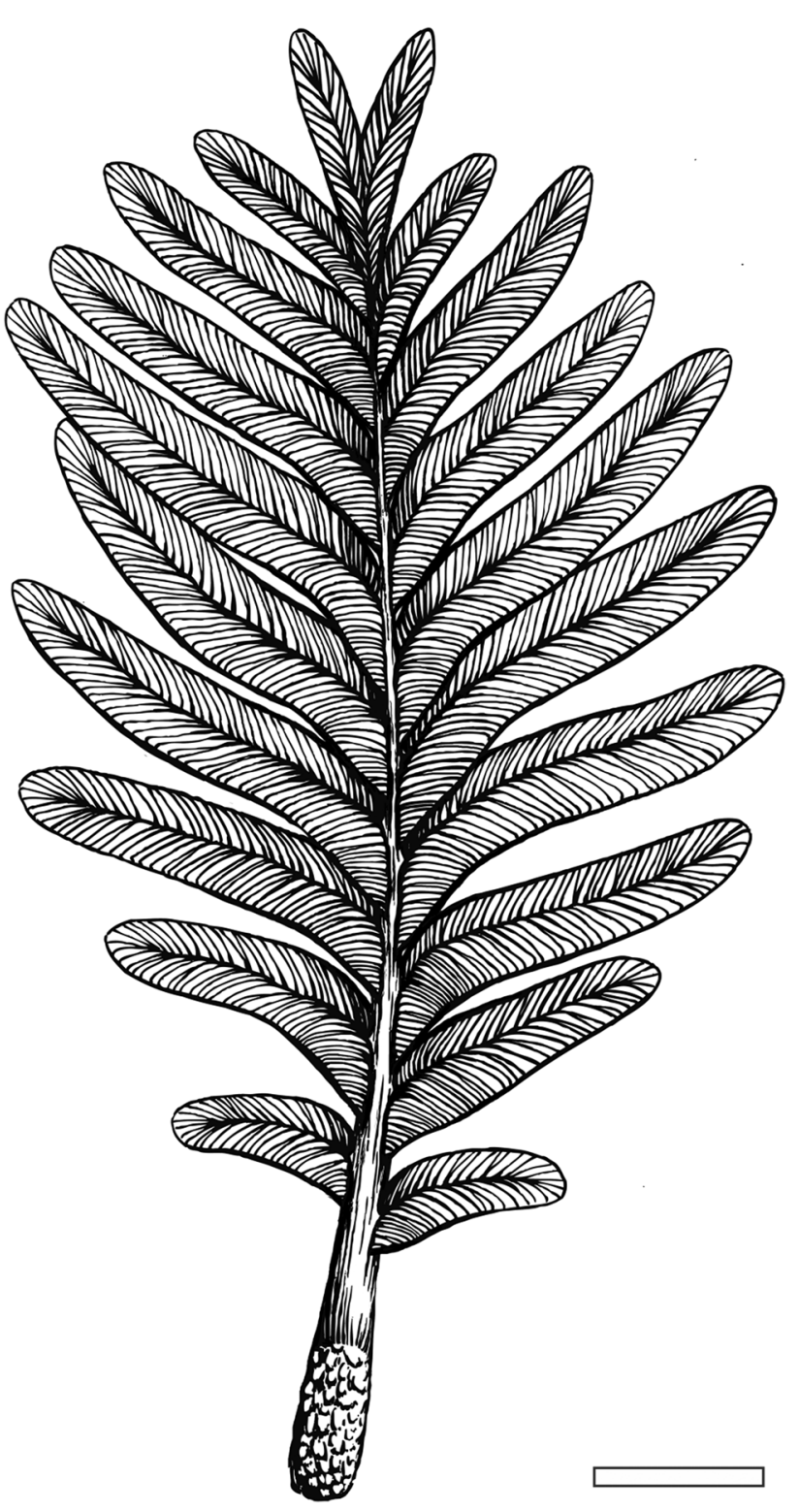

Fig. 5 Reconstruction of a Compsopteris wongii frond based on specimens PB22968 and PB22972, scale bar $5 \mathrm{~cm}$

was shown by Halle (1927: pl. XXXVI, fig. 5). This sample shows several juvenile fronds that arise from a rhizome, indicating that $C$. wongii might have had a shrub-like growth habit. However, this specimen is not well preserved, and the widened bases of several complete fronds in our collection indicate that they might have been shed from a major stem or branch of a tree. 


\section{Conclusions}

Cuticles of Compsopteris wongii from the Permian of Shanxi provide the first information on the epidermal anatomy of this enigmatic Cathaysian foliage taxon. Our results provide sound arguments for proposing an affinity of $C$. wongii to the seed fern order Peltaspermales, which are generally characterized by amphistomatic fronds with alethopteroid pinnules, callipterid venation, and haplocheilic stomata surrounded by one to three rings of subsidiary cells (Taylor et al. 2009; Retallack 1981; Bomfleur et al. 2011). Furthermore, our results allow a detailed comparison with possibly related peltaspermean genera (Tables 1,2). The similarities, especially with regard to the so-called glenopteroids Glenopteris and Nanshanopteris are sound enough to affiliate $C$. wongii with this group of putative Peltaspermales, as was previously proposed by Wan and Wang (2015). Due to the clear similarities of $C$. wongii to $C$. adzvensis and the problematic circumscription of Protoblechnum fossils from America, we follow Zalessky (1934) and include the Chinese material in the genus Compsopteris. Moreover, the limitation of Compsopteris to the Angaran realm (Naugolnykh 1999) is not in accordance with paragraph 38.3 of the International Code for Nomenclature for algae, fungi, and plants (Turland et al. 2018), which states that geographic features alone do not qualify as valid differentiating diagnostic criteria.

The depositional environment and epidermal anatomy indicate that Compsopteris wongii was an element of the peat-forming vegetation, along with noeggerathialeans, cordaitaleans, cycads, and other pteridosperms, confirming previous suggestions that peltasperms also inhabited everwet environments of Cathaysian coal swamps (Wang et al. 2014). Supaia and Nanshanopteris may be closely related forms that were adapted to more seasonally dry environments.

Acknowledgements We want to thank Dr. Liu Feng, Dr. Zhou Weiming, and Mr. Mei Shengwu for assistance during field work and collection studies at the Nanjing Institute of Geology and Palaeontology, as well Dr. Dieter Uhl, Dr. Michael Krings, Dr. Mike Reich, and Dr. Benjamin Bomfleur for their suggestions and constructive reviews that greatly improved this manuscript. We also thank Dora Schilling (Institute for Landscape Ecology, University of Muenster) for preparing the reconstruction of a frond of Compsopteris wongii. Technical and financial support was received from the National Natural Science Foundation of China (41872013 and 41530101), the Strategic Priority Research Program (B) of the Chinese Academy of Sciences (XDB18000000, XDB26000000), and the German Research Foundation (DFG grant KE584/21-1). This manuscript is an outcome of the Chinese-German joint research project "Late Palaeozoic Palaeobiology, Stratigraphy and Geochemistry," funded by the Sino-German Center for Research Promotion (Beijing), a cooperation of the National Natural Science Foundation of China and the German Research Foundation. This manuscript is dedicated to Professor Hans Kerp to honor his remarkable career and numerous contributions to paleobotanical research. He is also the one who made this contribution possible, as he found the Compsopteris-bearing sediments in the Palougou Section during field work in 2012 and proposed this section for a Sino-German joint $\mathrm{PhD}$ project.

Open Access This article is distributed under the terms of the Creative Commons Attribution 4.0 International License (http://creativeco mmons.org/licenses/by/4.0/), which permits unrestricted use, distribution, and reproduction in any medium, provided you give appropriate credit to the original author(s) and the source, provide a link to the Creative Commons license, and indicate if changes were made.

\section{References}

Andre, C.M., J.F. Hausman, and G. Guerriero. 2016. Cannabis sativa: The plant of the thousand and one molecules. Frontiers in Plant Science 7(19): 1-17.

Andrews, E.B. 1875. Descriptions of fossil plants from the Coal Measures of Ohio. Report of the Geological Survey of Ohio 2: 413-426.

Bomfleur, B., and H. Kerp. 2010. Dicroidium diversity in the Upper Triassic of north Victoria Land, East Antarctica. Review of Palaeobotany and Palynology 60(3-4): 67-101.

Bomfleur, B., E.L. Taylor, T.N. Taylor, R. Serbet, M. Krings, and H. Kerp. 2011. Systematics and paleoecology of a new peltaspermalean seed fern from the Triassic polar vegetation of Gondwana. International Journal of Plant Sciences 172: 807-835.

Chow, T.Y., S.J. Chang, and L.C. Chang. 1955. An additional specimen of forked frond of Protoblechnum wongii Halle. Acta Palaeontologica Sinica 3(3): 167-169. (in Chinese, English abstract).

Cross, A.T., H. Gillespie, and R.E. Taggert. 1996. Upper Paleozoic vascular plants. In Fossils of Ohio, ed. R.M. Feldmann. Ohio Division of Geological Survey Bulletin 70: 396-419.

Dawson, J.W. 1871. The fossil plants of the Devonian and Upper Silurian formations of Canada, 1-92. Montréal: Dawson Brothers. (Geological Survey of Canada).

Delevoryas, T. 1979. Cycadales: A brief note on their history. Cycadales Newsletter 3: 2-6.

DiMichele, W.A., H. Kerp, M. Krings, and D.S. Chaney. 2005. The Permian peltasperm radiation: Evidence from the southwestern United States. New Mexico Museum of Natural History and Science Bulletin 30: 67-79.

Du, X., and J. Zhu. 1982. The emendation of a cycad genus Yuania and the discovery of $Y$. chinensis sp. nov. Memoires of the Beijing Natural History Museum 17: 1-6. (in Chinese, English abstract).

Florin, R. 1933. Zur Kenntnis der paläozoischen Pflanzengattungen Lesleya Lesquereux und Megalopteris Dawson. Arkiv för Botanik A25: 1-23.

Gu, S.W.S., and W.S. Zhi. 1974. Part 1: Chinese palaeozoic plants. In An introduction to Chinese fossils, eds. L.H. Dong, X.X. Li, Z.Y. Zhou, R. Xu, and J.N. Zhu, 1-227. Beijing: Science Publishing House. (in Chinese).

Geinitz, H.B. 1855. Die Versteinerungen der Steinkohlenformation in Sachsen, 1-61. Leipzig: Engelmann.

Halle, T.G. 1925. Tingia, a new genus of fossil plants from the Permian of China. China Geological Survey, Bulletin 7: 1-12.

Halle, T.G. 1927. Palaeozoic plants from central Shansi. Palaeontologica Sinica (Series A) 2(1): 1-316.

Kaiser, H. 1976. Die permische Mikroflora der Cathaysia-Schichten von Nordwest-Schansi, China. Palaeontographica (B: Paläophytologie) 159: 83-157.

Kerp, H. 1990. The study of fossil gymnosperms by means of cuticular analysis. Palaios 5: 548-569. 
Kerp, H. 1996. Post-Variscan Late Palaeozoic Northern Hemisphere gymnosperms: The onset to the Mesozoic. Review of Palaeobotany and Palynology 90: 263-285.

Kerp, H., and M. Krings. 1998. Climbing and scrambling growth habits: Common life strategies among Late Carboniferous seed ferns. Comptes Rendus de l'Académie des Sciences (Series II A-Earth and Planetary Sciences) 326(8): 583-588.

Krings, M., and H. Kerp. 1997. An improved method for obtaining large pteridosperm cuticles. Review of Palaeobotany and Palynology 96: 453-456.

Krings, M., S.D. Klavins, W.A. DiMichele, H. Kerp, and T.N. Taylor. 2005. Epidermal anatomy of Glenopteris splendens Sellards nov emend., an enigmatic seed plant from the Lower Permian of Kansas (USA). Review of Palaeobotany and Palynology 136: 159-180.

Lesquereux, L. 1879-1880. Description of the Coal Flora of Pennsylvania and of the Carboniferous Formation throughout the United States. Harrisburg: Board of Commissioners. (Second Geological Survey of Pennsylvania, Report of Progress).

$\mathrm{Li}, \mathrm{X}$. 1995. Some notes on Carboniferous and Permian floras in China. In Fossil floras of China through the geological ages, ed. X. Li, 244-302. Guangzhou: Guangdong Science and Technology Press.

Liu, L.J. 1989. Discovery of bipinnatifid fronds of Protoblechnum wongii Halle with discussion. Acta Palaeontologica Sinica 28: 447-454. (in Chinese, English abstract).

Liu, F., H. Zhu, and S. Ouyang. 2011. Taxonomy and biostratigraphy of Pennsylvanian to Late Permian megaspores from Shanxi, North China. Review of Palaeobotany and Palynology 165: 135-153.

Liu, F., H. Zhu, and S. Ouyang. 2015. Late Pennsylvanian to Wuchiapingian palynostratigraphy of the Baode section in the Ordos Basin, North China. Journal of Asian Earth Sciences 111: 528-552.

Meyen, S.V. and A.V. Migdisova. 1969. Epidermal investigation of Angaran Callipteris and Compsopteris. In Pteridosperms of the upper Paleozoic and Mesozoic, ed. S.V. Meyen. Trudy Akademia Nauk SSSR 190:59-84. (in Russian).

Montañez, I.P., and C.J. Poulsen. 2013. The Late Paleozoic ice age: An evolving paradigm. Annual Review of Earth and Planetary Sciences 41: 629-656.

Montañez, I.P., N.J. Tabor, D. Niemeier, W.A. DiMichele, T.D. Frank, C.R. Fielding, J.L. Isbell, L.P. Birgenheier, and M.C. Rygel. 2007. $\mathrm{CO}_{2}$-forced climate and vegetation instability during Late Paleozoic deglaciation. Science 315: 87-91.

Mott, K.A., A.C. Gibson, and J.W. O'Leary. 1982. The adaptive significance of amphistomatic leaves. Plant, Cell and Environment 5: 455-460.

Naugolnykh, S.V. 1999. A new species of Compsopteris Zalessky from the Upper Permian of the Kama River basin (Perm Region). Palaeontological Journal 33: 686-697.

Naugolnykh, S.V., and H. Kerp. 1996. Aspects of Permian palaeobotany and palynology. XV. On the oldest known peltasperms with radially symmetrical ovuliferous discs from the Kungurian (uppermost Lower Permian) of the Fore-Urals (Russia). Review of Palaeobotany and Palynology 91: 35-62.

Poort, R.J., and J.H.F. Kerp. 1990. Aspects of Permian palaeobotany and palynology. XI. On the recognition of true peltasperms in the Upper Permian of Western and Central Europe and a reclassification of species formerly included in Peltaspermum Harris. Review of Palaeobotany and Palynology 63: 197-225.

Retallack, G.J. 1981. Middle Triassic megafossil plants from Long Gully, near Otematata, north Otago, New Zealand. Journal of the Royal Society of New Zealand 11: 167-200.
Sellards, E.H. 1900. A new genus of ferns from the Permian of Kansas. Kansas University Quarterly 9: 179-189.

Smith, W.K., T.C. Vogelmann, E.H. DeLucia, D.T. Bell, and K.A. Shepherd. 1997. Leaf form and photosynthesis. BioScience 47 (11): 785-793.

Sun, B.N., and G.L. Shen. 1999a. Discovery of bipinnatifid fronds of Protoblechnum contractum (Gu et Zhi). Chinese Science Bulletin 44: 381-383.

Sun, B.N., and G.L. Shen. 1999b. A supplementary study on Protoblechnum Lesquereux from China. Palaeobotanist 48: 125-129.

Sun, K.-Q. 2006. The Cathaysia flora and the mixed late Permian Cathaysian-Angaran Floras in East Asia. Journal of Integrative Plant Biology 48(4): 381-389.

Sze, H.C. 1955. On a forked frond of Protoblechnum wongii Halle. Acta Scientia Sinica 4: 12-24. (in Chinese, English abstract).

Taylor, T.N., E.L. Taylor, and M. Krings. 2009. Paleobotany: The biology and evolution of fossil plants. Amsterdam: Elsevier/Academic Press.

Turland, N. J., J.H. Wiersema, F.R. Barrie, W. Greuter, D.L. Hawksworth, P.S. Herendeen, S. Knapp, W.-H. Kusber, D.-Z. Li, K. Marhold, T.W. May, J. McNeill, A.M. Monro, J. Prado, M.J. Price and G.F. Smith, eds. 2018. International Code of Nomenclature for algae, fungi, and plants (Shenzhen Code) adopted by the Nineteenth International Botanical Congress Shenzhen, China, July 2017. Regnum Vegetabile 159: 1-254.

Wan, M., and J. Wang. 2015. Nanshanopteris nervosa gen. et sp. nov., a glenopterid foliage from the Changhsingian Sunan Formation in Yumen, western China. Review of Palaeobotany and Palynology 219: 39-51.

Wang, J., L. Liu, and H.W. Pfefferkorn. 2008. Recent advances on non-marine Late Paleozoic strata and floras: Outcome of the 16th International Congress on the Carboniferous and Permian. Episodes 31: 348-350.

Wang, J., H. Kerp, and H.W. Pfefferkorn. 2014. The earliest occurrence of peltasperms in the basal Permian strata of the North China Block and the radiation of this group. Geological Journal 49: 129-142.

Wang, J., H.W. Pfefferkorn, Y. Zhang, and Z. Feng. 2012. Permian vegetational Pompeii from Inner Mongolia and its implications for landscape paleoecology and paleobiogeography of Cathaysia. Proceedings of the National Academy of Sciences 109: 4927-4932.

Wang, Y., and S. Chen. 2016. Meandering river sand body architecture and heterogeneity: A case study of Permian meandering river outcrop in Palougou, Baode, Shanxi Province. Petroleum Exploration and Development 43: 230-240.

Wang, Z.-Q. 1997. Permian Supaia fronds and an associated Autunia fructification from Shanxi, China. Palaeontology 40: 245-277.

Werker, E. 2000. Trichome diversity and development. In Advances in botanical research incorporating advances in plant pathology, vol 31: Plant trichomes, eds. D.L. Hallahan and J.C. Gray, 1-35. San Diego: Academic Press.

White, D. 1929. Flora of the Hermit Shale, Grand Canyon, Arizona. Carnegie Institution of Washington Publication 405: 1-221.

Zalessky, M. 1934. Observations sur les végétaux permiens du bassin de la Petchora. I. Bulletin de l'Académie des Sciences de l'URSS 2/3: 241-290. 